\title{
構造用集成材を用いたアー チ式架構とポストアンドビ 一ム式架構の施工人工数に 関する調查報告 \\ THE REPORT ON MAN-HOUR OF ERECTION OF ARCH AND POST-AND-BEAM CONSTRUCTION BY GLUED LAMINATED TIMBER
}

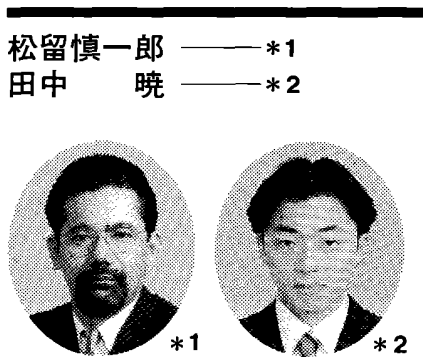

\section{Shinichiro MATSUDOME \\ Satoru TANAKA}

In this study we report about man-hour of erection and program of works of arch and post-and-beam construction by glued laminated timber. On this report we grasped the basic man-hour of erection and program of works and investigated its characteristic on arch and post-and-beam construction by glued laminated timber.

We surveyed three site of erection with arch and other three site of erection with post-and-beam. As a result we find that man-hour are influenced by many conditions and write down the conditions.

キーワード :

構造用集成材, 施工人工数, アーチ, ポストアンドビーム, ユニット, 地組架構体
Keywords :

glued laminated timber, man-hour of erection, arch, post-and-beam, unit, ZIGUMI frame

\section{1 目的}

昭和 62 年の建築基準法改正をはじめ, 関係法令の改正により,大 断面構造用集成材を使用した木造建築物が建築可能となって以来, 構造用集成材を用いた大規模木造建築物は増加してきている。しか し，集成材による大架構木造建築物を設計する際どの架構方式を選 択するか，また，どのように工程計画を立てるか，その指標がほと んどなく，担当者個人の力量に頼っているのが現状である。

本研究は，架構形式選択のための生産上の指標作成，及び，設計 完了時での建方に関する施工人工数の予測と工程計画のプログラム 作成を最終的な目標としている。そのために，構造用集成材を用い た木造建築物について, 基本設計が完了した時点で施工人工数や工 期等の工程計画が従来よりも詳細に立案できるような基礎的なデー
タを収集することが必要となる。

本編では，その目標に従い建方調查を実施したアーチ式架構 3 例 とポストアンドビーム式架構 3 例に関する，施工人工数と工程，さ らに，施工人工数に影響を与えた条件について，報告している。

\section{2 調查概要}

\section{1 調査対象}

アーチ式架構 3 物件, ポストアンドビーム式架構 3 物件, 計 6 物 件に対して建方調査を実施した。調査対象の概要は表 1 のとおりで ある。

\section{2 調查期間}

調査期間は平成 5 年 10 月から平成 6 年 11 月である。各調査対象 における建方の調査期間は，表 1 に扔ける工事期間に相当する。

表 1 調查対象の概要と基本的な施工人工数

\begin{tabular}{|c|c|c|c|c|c|c|}
\hline 調查対象物件 & 物件 $\mathrm{A}$ & 物件 $\bar{B}$ & 物件C & 物件D & 物件E & 物珄F \\
\hline 所在 & 北海道夕張郡 & 福岡県久留米市 & 和歌山県龍神村 & 神奈川県箱根町 & 秋田県能代市 & 能本県高森町 \\
\hline 工事期間 & $93 / 10 / 28 \sim 11 / 8$ & $93 / 11 / 10 \sim 12 / 04$ & $93 / 12 / 9 \sim 12 / 25$ & $94 / 7 / 29 \sim 8 / 8$ & $94 / 8 / 17 \sim 9 / 21$ & $\cdot 94 / 11 / 21 \sim 11 / 28$ \\
\hline 架構方式 & アーチ & アーチ & アーチ & ポ元アンドビーム & ポストアンドビーム & ポ䄭アンドビーム \\
\hline 建築面積 (m2) & 1449.439 & 833.356 & 530.800 & 336.720 & 686.400 & 202.900 \\
\hline 総材積 $(\mathrm{m} 3)$ & 72.524 & 61.110 & 42.050 & 31.320 & 80.373 & 69.740 \\
\hline \multirow{2}{*}{ 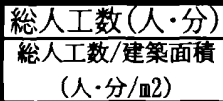 } & 24271 & 66718 & 25523 & 38761 & 61545 & 24989 \\
\hline & 16.75 & 80.06 & 48.08 & 115.11 & 89.66 & 123. 16 \\
\hline 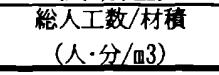 & 334.66 & 1091.77 & 606.97 & 1237.58 & 765.74 & 358.32 \\
\hline
\end{tabular}

\footnotetext{
${ }^{*}$ 職業能力開発大学校建築工学科 助教授 $\cdot$ 工博 $* 2$ 職業能力開発大学校研究課程
}

${ }^{* 1}$ Assoc. prof., Dept. of Architectural Engineering, The Polytechnic University, Dr. Eng.
Graduate Student, The Polytechnic University. 


\section{3 調查方法}

調査員が現場作業を観察し, 準備した各コードに基づき調査用紙 に記入した。確認の意味を含めて各作業の区切り毎に写真撮影もお こなった。記入内容は下記のとおりである。(1)職種, (2)作業開始時 間, (3)作業終了時間, (4)対象部材, (6)位置, (7)作業内容, (8)備考

\section{3 結果}

施工人工数を論ずる時には，床面積あたりとか，使用材積あたり とか, 比較検討のための数值で除して表記するのが常識であろう。 本研究でも, 上記以外に, 接合方式，接合数，部材数，など様々な 数值を用いて比較のための検討をおこなったが，効果的に説明でき る項目が見いだせなかった。ここでは，建築面積あたり，および， 材積あたりの結果を，表 1 に示すにとどまっている。一方で，レッ カーで吊り込む単位となる地組された架構の大きさとその数が, 建 方の効率に大きく影響することがわかり，「地組架構体」と「ユニッ ト」の概念を導入し，以下のように定義している。

「躯体を構成する主要な梁, 柱, 小屋組等を地組した構造体」を「地 組架構体」と定義。地組作業で取り付けることが可能な部材（金属 を含む）は，地組架構体として吊り込み作業を行った方が，作業能 率はよい。また，「地組架構体 1 組に 1 ピッチに相当する梁・ブレー ス・母屋等を加えた単位」を「1ユニット」と定義。1 ユニットあた りの数值は, 地組架構体については地組架構体数, 梁・ブレース・ 母屋に対してはピッチ数で全体を割って算出している。

\section{1 物件別総人工数及び内訳}

図 1 はアーチ式架構の物件別総人工数の内訳を面積比率によっ て表している。物件 B は物件 A と物件 C に比べて, 2 倍以上の総人 工数になっている。各作業の割合は, 物件 A と物件 C がほぼ同じ傾 向を示している。しかし, 物件 B は他の 2 物件に比べてュニット標 準作業が 20 ポイント以上少なく，ユニット外標準外作業が約 10 ポ イント，標準外作業が 15 ポイント以上多くなっている。これは， 1 日当たりの出面数が多かったこと, また複雑な架構デザインで加工 ミスもあったことなどが重なって，上記のような結果になっている。 アーチ式架構の場合, 架構が比較的単純なため, 総人工数は建築面 積や総材積など規模的な要因では，それほど大きく変化しない。し かし, 物件 Bのように複雑な架構デザインとなると, 総人工数とユ ニット標準の割合が多くなってしまう。

図 2 はポストアンドビーム式架構の物件別総人工数の内訳を面 積比率によって表している。物件 $\mathrm{E}$ は他の 2 物件に比べて, 総人工 数が極端に多くなっている。これは建築規模を考えると当然の結果 といえる。また, 物件 E の準備が他の物件に比べ $14.9 \%$ と多くなっ ているのは, 現場規模が大きいことに加え, $\mathrm{RC}$ 部分等の他職種に関 係する部分が多かったためである。各作業の割合については，物件 E と物件 F は，準備を除いてほほ同じ傾向を示している。しかし， 物件 D は他の 2 物件に比べて，ユニット標準作業が 20 ポイント以 上少なく，ユニット外標準作業，標準外作業，休みが多くなってい る。これは，母屋金物の取り付け位置が墨付けされていなかったた め，母屋金物を地組作業の際に取り付けず部材吊り込み後に架構の 上で取り付けた結果，作業効率が悪くなったためである。また，加 工精度が悪く，加工ミスによる手直し加工が多かったことも影響し ている。加えて，工事期間が 7 月下旬から 8 月上旬までと暑い時期

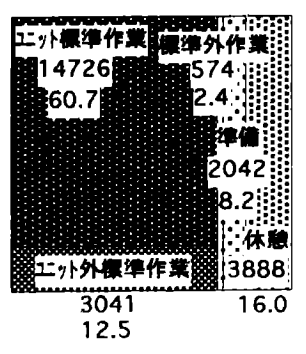

物件A 24271 人.分
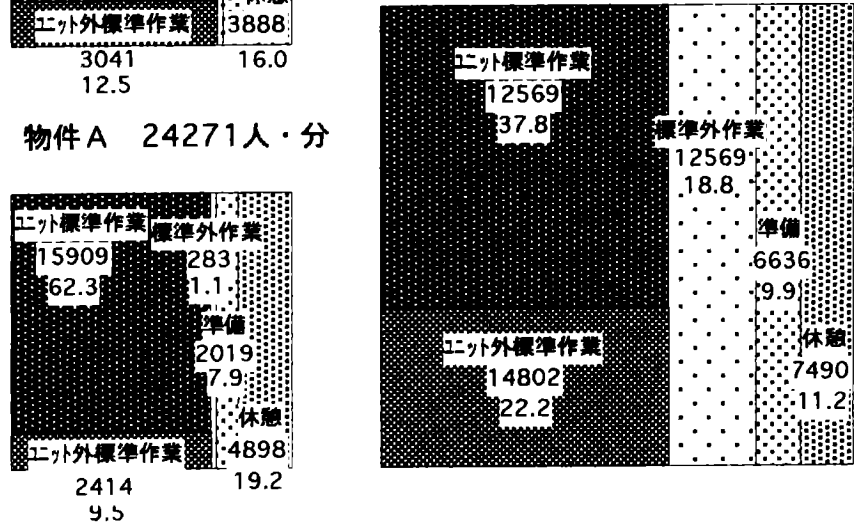

物件 C 25525 人. 分 物件 B 66718 人·分

図 1 総施工人工数内訳比率図 (アーチ式架構)

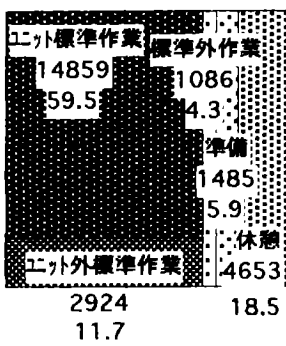

图中の数辛は上段が人工数（人・分） 下段は総人工数に対する㔊合（\%)

物件 F 24989 人. 分

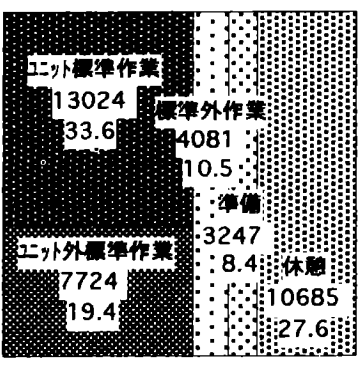

物件D 38716 人・分

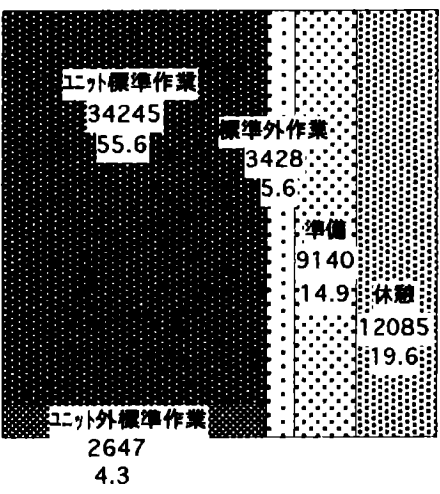

物件 E 61545 人・分

図 2 総施工人工数内訳比率図 (ポストアンドビーム式架構)

であり，休みを多く取らざるを得なかったことも原因として挙げら れる。

ポストアンドビーム式架構は，アーチ式架構に比べて複雑な架構 となることが多い。そのため，同じような規模の場合，ポストアン ドビーム式架構の方が総人工数が多くなる。

6 物件の各作業内容の割合は，物件 $\mathrm{A}$, 物件 $\mathrm{C}$, 物件 $\mathrm{F}$ が同じ傾 向を示している。物件 $\mathrm{E} も ，$ 準備を除いて同じ傾向を示している。

3.2 ユニット標準作業

3. 2.1 ユニット別標準作業人工数

a) アーチ式架構

図 3 は物件 A のユニット別標準作業人工数を示している。X 2 か 
ら地組及び吊り込み作業が始まっており，X 2 が他のユニットに比 べて人工数が多い。これは職人の慣れが影響している。X 2 以外の工 ニットは，ほほ同じ值を示している。な㧈，図30X9のように值 が極端に少なくなっているのは，妻面であるために母屋や梁の吊り 込みが無かったためである。

図 4 は物件 B のユニット別標準作業人工数を示している。物件 B では，最初に地組作業をおこなった $1(\mathrm{H})$ の人工数が他のユニット より突出している傾向が, 物件 A よりも顕著である。これは, $1(\mathrm{H})$ が最初のユニットであるということに加え，左右対称の 2 連のアー チが並ぶため部材位置を特定するのが難しかったこと，さらに，部 材や金物の種類が多かったためである。A 側のユニットは, 後作業 であることに加え部材や金物の種類が少ないために，H 側に比較し て人工数が少なくなっている。

図 5 の物件 C は, 最初のユニットから順に標準作業人工数が少な くなっているという点で，他の 2 物件と同じ傾向を示している。

b）ポストアンドビーム式架構

図 6 は物件 Dのユニット別標準作業人工数を示している。物件 D の場合, 同時に 2 組の地組架構体を地組しており,ここでは, 2 組分 の人工数を 2 で割って，1 ユニットの人工数としている。地組作業

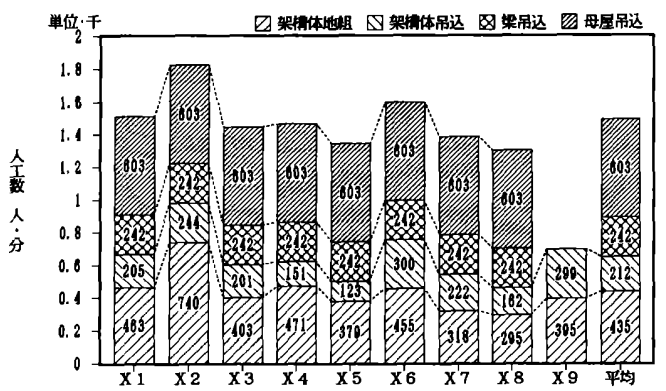

図 3 物件 $\mathrm{A}$ のユニット別標準作業

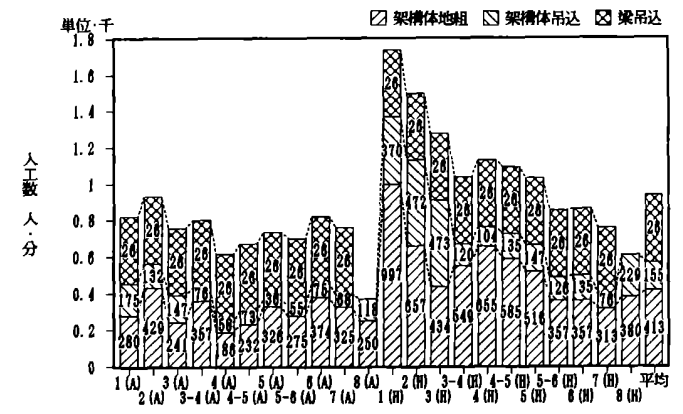

図 4 物件 B のユニット別標準作業

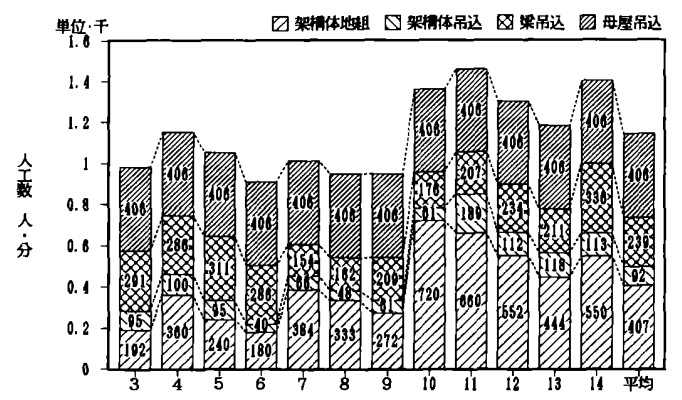

図 5 物件 Cのユニット別標準作業
は，[1・5]，[2・6]，[4・8]，[3・7]のセットで，吊り込み作業は，5， $1 ， 6 ， 2 ， 8 ， 4 ， 7 ， 3$ の順で，作業が進んでいる。始めに吊り込み作 業を㧈こなった 1 と 5 のユニットが，他と比較して人工数が多い。 職人が慣れたのは 3 ユニット目以降である。

図 7 は物件 $\mathrm{E}$ のユニット標準作業人工数を示している。物件 $\mathrm{E}$ の

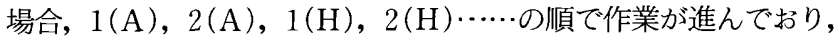
物件 D と同じく，最初に地組と吊り込みをおこなった $1(\mathrm{~A})$ の人工 数が最も多く，作業が進むにしたがい職人が慣れてゆき人工数は減 少するという傾向を示している。

図 8 は, 物件 F のユニット標準作業人工数を示している。妻面の 1 と 10 のユニットは, 材積で他のユニットの 2.5 倍と柱数が多く, 地組架構体 2 (胴差十柱) の地組と吊り込み作業に多くの人工数がか かっている。地組架構体 1 (小屋組)の地組と吊り込み作業に関して は, 2〜9 のユニットの中では最初に作業をおこなった 2 のユニット の人工数が最も多く，他の 2 例と同じょうな傾向を示している。

\subsubsection{1 ユニットあたりの平均標準作業人工数}

表 2 は 1 ユニットあたりの標準作業人工数を比較したものであ る。また，人工数に影響を与える可能性のある内容のうち，建物そ のものに関する項目（ハード）を表 3 に示す。

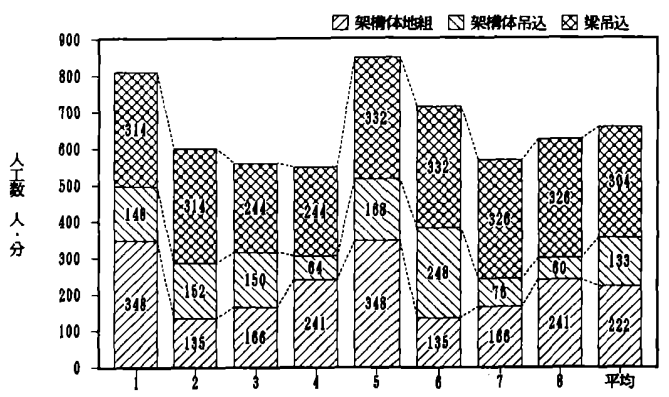

図 6 物件 D のユニット別標準作業

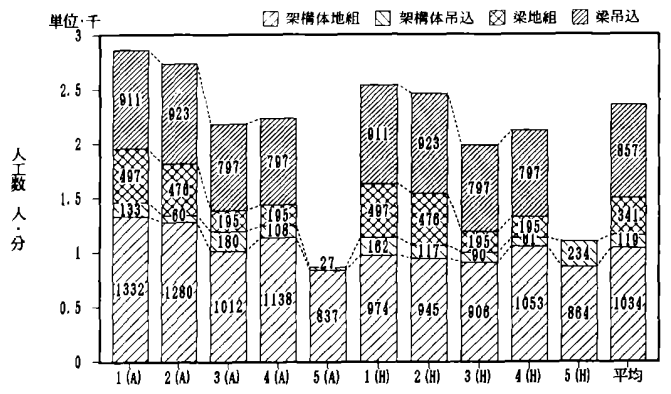

図 7 物件 E のユニット別標準作業

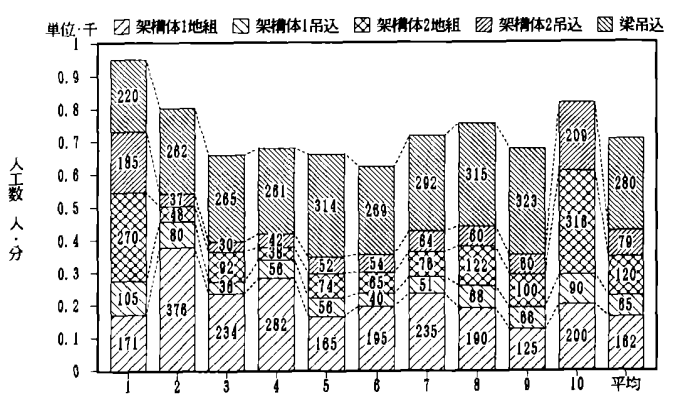

図 8 物件 F のコニット別標準作業 
a）アーチ式架構

地組架構体の地組作業は材積やスパンが異なるにも関わらず，3 物件がほぼ同じ人工数になっている。例えば, 物件 B は小型の地組 架構体で材積も少ないが，ドリフトピンの打ち込みに相当手間取っ ていた。接合数はどの地組架構体でも大差がないことも考えあわせ ると，材積やスパンに加え，接合方式の影響も大きいと指摘できる。 地組架構体の吊り込み作業にも地組架構体の材積やスパンが影響 を与えるが，接合方式の影響も小さくない。接合数はどの地組架構 体でもほぼ同じであった。吊り込み作業には部材が大きく重い方が 時間がかかるのは当然であり，例えば，最も材積の大きい物件 Aに おいて吊り込みの人工数が最も多くなってる。物件 B は吊り込み作 業時のドリフトピン接合に手間取っている。結果として, 材積やス パンが最も小さい物件 Cよりも吊り込みの人工数が多くなってい る。また, 梁や母屋の吊り込み作業では, 接合数と接合方式の影響 が圧倒的に大きかった。

b）ポストアンドビーム式架構

地組架構体の地組作業は, 物件 E が他の 2 物件に比べ突出して多 い。物件 $\mathrm{E}$ の場合，最も材積が大きい，接合数が 8 ケ所と多いとい うことに加え，金物十ボルト接合であり，しかも，1 つの接合部当た りのボルト数が多いために，ボルト締めに相当な時間がかかり，上

表 21 ユニット当たりの標準作業人工数

\begin{tabular}{|c|c|c|c|c|c|c|}
\hline & $\begin{array}{c}\text { 架構体 } \\
\text { 地組 } \\
\text { 人.分 }\end{array}$ & $\begin{array}{c}\text { 架構体 } \\
\text { 吊込 } \\
\text { 人.分 }\end{array}$ & $\begin{array}{l}\text { 梁吊込 } \\
\text { 人. 分 }\end{array}$ & $\begin{array}{l}\text { 母屋 } \\
\text { 吊込 } \\
\text { 人.分 }\end{array}$ & $\begin{array}{l}7 * V-\lambda \\
\text { 吊込 } \\
\text { 人.分 }\end{array}$ & $\begin{array}{l}\text { 合計 } \\
\text { 人.分 }\end{array}$ \\
\hline 物件 $\mathrm{A}$ & 435 & 221 & 242 & 603 & & 1492 \\
\hline 物件 B & 413 & 155 & 369 & & & 937 \\
\hline 物件 C & 407 & 92 & 239 & 406 & & 1144 \\
\hline 平均 & 418 & 153 & 283 & 505 & & 1359 \\
\hline 物件 D & $\overline{222}$ & $\overline{133}$ & 304 & $\overline{464}$ & & 1123 \\
\hline 物件 E & 1034 & 119 & 857 & 558 & 688 & 3256 \\
\hline 物件 F & 282 & 144 & 280 & 97 & 191 & 994 \\
\hline 平均 & 513 & 132 & 432 & 373 & 436 & 1877 \\
\hline
\end{tabular}

*1 空棵は該当する部材がないことを示す。
述の結果となった。物件 D は，接合方式が金物十ボルト接合である にもかかわらず，地組作業の際に母屋金物を取り付けなかったため に地組作業の施工人工数が最も少なくなっている。物件 F の場合, 接合数は 8 ヶ所と多いが在来の継手仕口を使用しているために人 工数は相殺されて抢り，材積なりの人工数となっている。地組作業 は地組架構体の材積やスパンも影響するが, それ以上に, 接合数や 接合方式の影響が大きいと指摘できる。

地組架構体の吊り込み作業は, 3 物件ともほぼ同じ人工数になっ ている。地組架構体の吊り込みに関係する接合数や接合方式は 3 事 例ともほぼ同じで, 材積やスパンの大きい物件 Eが人工数も最も多 くなると予想されたが結果は逆であった。物件 D と物件 F の職人 は集成材の建方工事が今回初めてであったが, 物件 E の職人は経験 が豊富であり吊り込み作業が極めてスムーズで，職人の慣れの程度 も影響を与えるということが確認できた。また，母屋吊り込みの人 工数については,物件 D では母屋金物の取り付けも同時におこなっ たために多く,物件 F では在来の継手仕口であったために少なくな っている。

\section{3 職人別人工数}

表 4 は, 6 物件の職人別の人工数とその割合を示している。物件 C と物件 E において大工が 70\%以上占めているのに対し, 物件 A•物 件 B・物件 D・物件 F では氛が 65\%〜75\%を占めている。大工中心 のチーム編成と蔦中心のチーム編成でどちらが良いかは, 一概には 言えない。蔦中心のチーム編成の方が建方は効率的ではある。しか

表 5 平均的チーム編成

\begin{tabular}{|c|c|c|c|c|c|c|}
\hline & 物件 A & 物件 B & 物件 C & 物件D & 物件 $\mathrm{E}$ & 物件F \\
\hline 大工（人) & $\overline{0}$ & $\overline{0}$ & 5 & 7 & 7 & 2 \\
\hline 蔦(人) & 4 & 5 & 0 & 2 & 0 & 6 \\
\hline 重機(人) & I & 1 & 1 & 1 & 1 & 1 \\
\hline 管理 (人) & $\bar{I}$ & 1 & 1 & 1 & 1 & 1 \\
\hline 合計(人) & 6 & 7 & 7 & 11 & 9 & 10 \\
\hline
\end{tabular}

表 3 調查対象の仕様

\begin{tabular}{|c|c|c|c|c|c|c|c|c|c|c|c|c|}
\hline & \multicolumn{4}{|c|}{ 単位材積(m3/エニット) } & \multirow{2}{*}{$\begin{array}{c}\text { 総材積 } \\
\text { (m3) }\end{array}$} & \multirow{2}{*}{$\begin{array}{c}\text { スパン } \\
\text { (mm) }\end{array}$} & \multirow{2}{*}{$\begin{array}{c}\text { ピッチ } \\
\text { (mm) }\end{array}$} & \multirow{2}{*}{$\begin{array}{l}\text { 高さ } \\
\text { (mm) }\end{array}$} & \multirow{2}{*}{$\begin{array}{l}\text { 架構 } \\
\text { 体数 }\end{array}$} & \multirow{2}{*}{$\begin{array}{l}ヒ^{\circ} \times f \\
\text { 数 }\end{array}$} & \multirow{2}{*}{$\begin{array}{c}\text { 接合 } \\
\text { 数 }\end{array}$} & \multirow[t]{2}{*}{ 接合方式 } \\
\hline & 架構体 & 梁 & ブレース & 母屋 & & & & & & & & \\
\hline 物件 A & 5.03 & 1.78 & & 3.37 & 72.5 & 24000 & 4000 & 9600 & 9 & 8 & 3 & 金物+ボル卜 \\
\hline 物件 B & 0.67 & 0.77 & & & 61.1 & 10000 & 3000 & 6000 & 22 & 20 & 1 & ドリ7トピソ \\
\hline 物件 C & 2.49 & 0.27 & & 0.98 & 42.1 & 16000 & 2000 & 8500 & 14 & 13 & 1 & 金物十ボル卜+釘 \\
\hline 物件D & 1.46 & 2.23 & & 0.22 & 31.3 & 10755 & & 7770 & 8 & 8 & 3 & 金物+ボル下 \\
\hline 物件 E & 4.56 & 3.19 & 2.23 & 2.20 & 80.3 & 28600 & 3000 & 5900 & 10 & 8 & 8 & 金物+林小 \\
\hline 物件F & 2.01 & 1.31 & 0.44 & 0.18 & 69.7 & 14400 & 1800 & 10470 & 10 & 9 & 8 & 継手仕口 \\
\hline
\end{tabular}

表 4 職人別施工人工数

\begin{tabular}{|c|c|c|c|c|c|c|c|c|c|c|c|c|c|c|c|c|c|c|}
\hline \multirow[t]{2}{*}{ 職種 } & \multicolumn{3}{|c|}{ 物件 $\mathrm{A}$} & \multicolumn{3}{|c|}{ 物件 B } & \multicolumn{3}{|c|}{ 物件 C } & \multicolumn{3}{|c|}{ 物件 D } & \multicolumn{3}{|c|}{ 物件 $\mathrm{E}$} & \multicolumn{3}{|c|}{ 物件 F } \\
\hline & - 分 & $\begin{array}{l}\text { 人·分 } \\
\text { /工外 }\end{array}$ & $\%$ & 人.分 & $\begin{array}{l}\text { 人·分 } \\
\text { /Iニ卟 }\end{array}$ & $\%$ & 人.分 & $\begin{array}{l}\text { 人・分 } \\
\text { /工二卟 }\end{array}$ & $\%$ & 人.分 & $\begin{array}{l}\text { 人·分 } \\
\text { /工二卟 }\end{array}$ & $\%$ & 人·分 & $\begin{array}{l}\text { 人·分 } \\
\text { /工二ッ卜 }\end{array}$ & $\%$ & 人.分 & $\begin{array}{l}\text { 人·分 } \\
\text { /工二外 }\end{array}$ & $\%$ \\
\hline 工 & $\overline{306}$ & 145.1 & 5.4 & 3825 & 173.9 & 5.4 & 20801 & 1485.8 & 81.5 & $\overline{9091}$ & 1136.4 & 23.5 & 44306 & $\overline{4430.6}$ & 72.0 & 5305 & 530.5 & 22.1 \\
\hline 蔦 & 18445 & 2049.4 & 76.0 & 51173 & 2326.0 & 76.7 & 0 & 0.0 & 0.0 & 25621 & 3202.6 & 66.1 & 6558 & 655.8 & 10.7 & 15209 & 1520.9 & 63 \\
\hline 重機 & 2771 & 307.9 & 11.4 & 9853 & 447.9 & 14.8 & 3393 & 242.4 & 13.3 & 2754 & 344.3 & 7.2 & 8252 & 825.2 & 13.4 & 3461 & 346.1 & 10.3 \\
\hline 管理 & 1354 & 150.4 & 1.6 & 1580 & 71.8 & 2.4 & 1329 & 94.9 & 5.2 & 1135 & 141.9 & 2.7 & 2191 & 219.1 & 3.5 & 763 & 76.3 & 3.2 \\
\hline その他 & 395 & 43.9 & 5.6 & 282 & 12.8 & 0.4 & 0 & 0.0 & 0.0 & 130 & 16.3 & 0.3 & 238 & 23.8 & 0.4 & 251 & 25.1 & 1.0 \\
\hline 合計 & 24271 & 2696.8 & 00.0 & 66718 & 3032.6 & 100.0 & 5523 & 1823.1 & 00.0 & 38731 & 4841.4 & $\overline{00.0}$ & 61545 & 6154.5 & 100.1 & 24989 & 2498.9 & 100. \\
\hline
\end{tabular}


し，大工が鶚的な作業も十分にこなせるのなら，手直し等を数多く 必要とする現場では大工中心のチーム編成の方が現場加工に対応し やすい分だけうまくゆく。また，集成材の建方工事ではクレーンを 必ず使用している。平均的チーム編成については，表 6 に示す。

\section{4 日別人工数累積}

図 9 は, 6 物件の日別人工数の累積図である。物件 B と物件 $\mathrm{E}$ は, 他の物件に比べ工期が長く，総人工数も多くなっている。物件 B の 作業日数が多いのは，一部に細かい間仕切があったりアーチが 2 連 並ぶなど複雑な架構デザインとなっており，作業がスムーズに進行 しなかったためである。また，加工ミスによる現場での手直し加工 等の標準外作業が多いことも，原因のひとつである。物件 $\mathrm{E}$ は，建 築規模が大きいことに加えて $\mathrm{RC}$ 部分の工事の遅れに影響されて 予定の工程どおりに工事が進まなかった。物件 B と物件 $\mathrm{E}$ の職人 は，集成材の建方の経験が豊富であったために，段取りや作業スピ ードについては優れていた。しかし，経験豊かな職人であっても， 架構の複雑さや工程の遅れを十分にカバーすることはできなかっ た。

物件 D の場合，1日の平均出面数が多いこと，職人が集成材の建 方工事が始めてであったこと，工事期間が猛暑であったこと等が重 なり，建築規模や材積が他の事例よりも少ないにもかかわらず，総 人工数が多くなり，工期も同じような長さになった。

物件 $\mathrm{A} ・$ ・物件 $\mathrm{C} ・$ 物件 $\mathrm{F}$ は, 総人工数も工期も同じような傾向を 示している。特に，物件 F は職人が集成材の建方工事が初めてであ ったにもかかわらず，他に好条件が重なったために，総人工数も工 期も物件 A や物件 C と同じような傾向を示している。

\section{4 施工人工数や工期にみられる特徵と影響を与えた 条件}

以上の分析で述べてきたように，施工人工数や工期は条件により 影響を受ける。ここでは, 調査対象 6 物件について, 調査結果から
指摘できる施工人工数や工期にみられる特徵と，施工人工数や工期 に影響を与えた条件について整理している。なお，ハードとソフト などの分類は抢こなわず，項目を単純に列記している。

(1) 物件 A

特徴

・総人工数，工期，各作業の割合は，標準的である。

影響を与えた条件

・接合方式が金物十ボルト接合である。

・加工精度が良い。

・職人は集成材の建方工事の経験が豊富である。

(2) 物件 B

特徵

・総人工数が多く，工期が長い。

・ユニット標準作業の割合が少なく, ユニット外標準作業, 標準外 作業の割合が多い。

影響を与えた条件

・接合方式が金物+ドリフトピン接合である。

・加工精度が悪い。

・複雑な架構デザインである。

・職人は集成材の建方工事の経験が豊富である。

(3) 物件 C

特徴

・総人工数，工期，各作業の割合は標準的である。 影響を与えた条件

・接合方式が金物十ボルト十釗接合である。

・加工精度が良い。

・職人は集成材の建方工事の経験が豊富である。 (4) 物件 D

特徵

・想像以上に総人工数が多く，工期が長い。

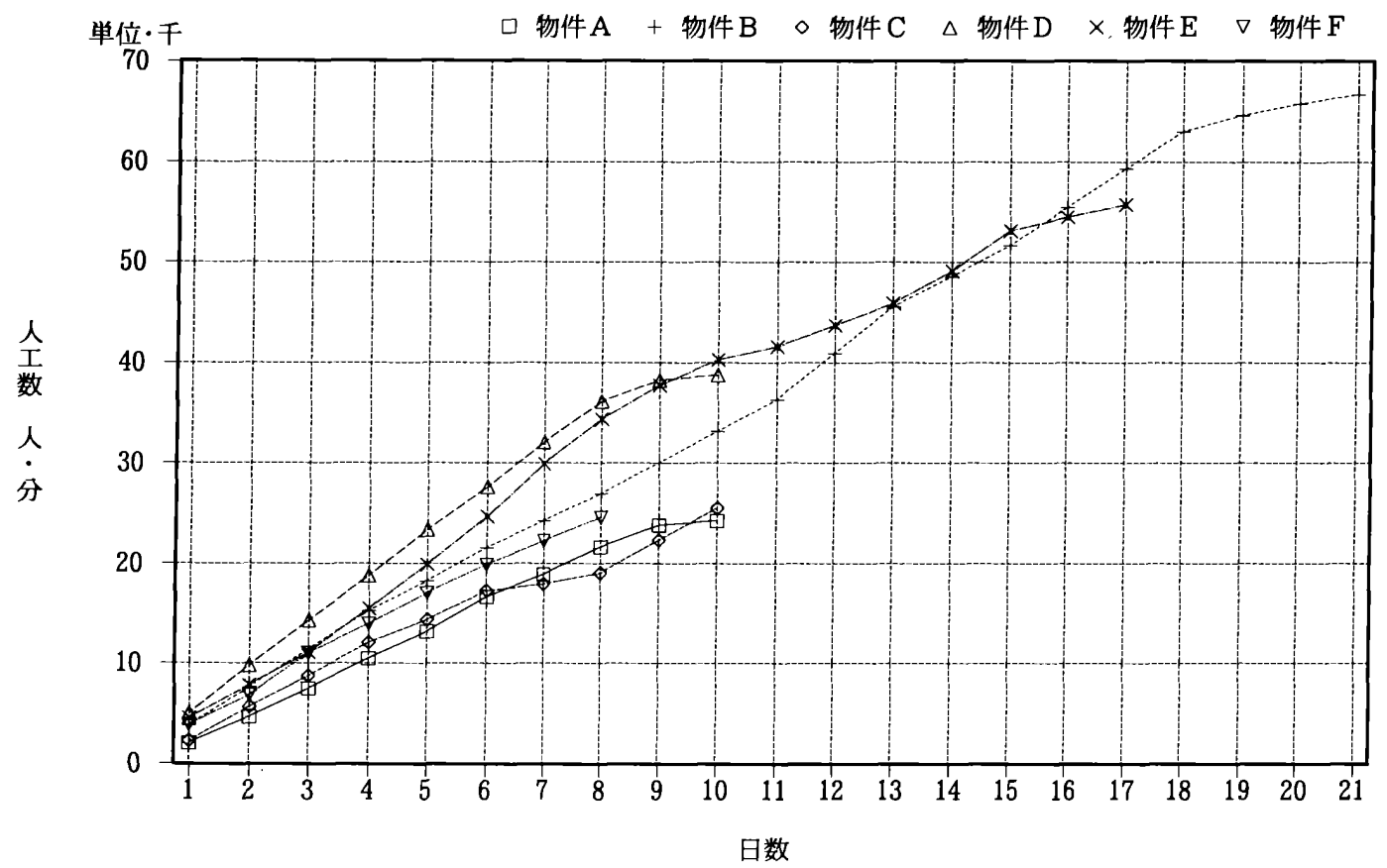

図 9

日別施工人工数累積図 
・ユニット標準作業の割合が少なく, ユニット外標準作業, 標準外

作業，休みの割合が多い。

影響を与えた条件

・接合方式が金物十ボルト接合である。

・加工精度が悪い。

・職人は集成材の建方工事が始めてである。

・地組架構体の地組の際，母屋金物を取り付けていない。

・工事時期が猛暑であった。

(5) 物件 E

特徴

・総人工数が多く，工期が長い。

・準備等を除いて，各作業の割合は標準的である。

影響を与えた条件

・金物十ボルト接合で，ボルト数が多い。

・接合数が多い。

・加工精度が悪い。

・建築規模が大きい。

・職人は集成材の建方工事の経験がある。

(6) 物件 F

特徵

・総人工数，工期，各作業の割合は標準的である。

影響を与えた条件

・接合方式が在来の継手仕口である。

・接合数が多い。

・加工精度がよい。

・架構が比較的単純である。

\section{5 おわりに}

本編では, アーチ式架構 3 件とポストアンドビーム式架構 3 件に ついて，その建方に関する施工人工数や工期等の基礎的なデータを 報告している。また，「地組架構体」や「ユニット」という概念を導 入することにより，建方に関する施工人工数や工期を理解し易くな ることがわかった。さらに，施工人工数は様々な条件により大きく 異なることが確認でき，施工人工数に影響を与える条件についても 整理している。今後は, さらに調査事例を増やすことはもちろんの こと，施工人工数に影響を与える条件について，その影響の程度の 把握や各作業の標準的数值の推測等をおこない, 設計完了時に建方 に関する施工人工数と工期の試算ができるような方法論を見い出す ことが大きな目標となる。

\section{6 謝 辞}

本調査研究を進めるにあたっては, 三井木材工業株式会社の宮林
正幸氏，鳥羽展彰氏をはじめとする関係各位の協力と，当時の卒論 生である原田貴透君 (平成 5 年度), 児玉忍君 (平成 6 年度) の勢力 的な調查に因るところが大きいことを記して感謝したい。

\section{参考文献}

1）松留慎一郎：構造用集成材を用いたアーチ式木造架構の施工人 工数に関する調査研究, 日本建築学会第 10 回「建築生産と管理 技術」シンポジウム論文集, pp. 545〜 552, 1994. 7

2）西村慶徳, 須田松次郎, 藤澤好一：大規模木造建築物の施工管理 に関する諸問題, 日本建築学会第 4 回「建築生産と管理技術」シ ンポジウム論文集, pp. 23〜26, 1988. 7

2）西村慶徳, 須田松次郎, 藤澤好一：大規模木造建築の生産供給体 制と施工管理に関する考察, 日本建築学会第 5 回「建築生産と管 理技術」シンポジウム論文集, pp. 61〜 64, 1989. 7

3）太田芳夫, 藤澤好一, 吉田倬郎, 松留慎一郎, 松田尚人： $2 \times 4$ 構法 のフレーミング工事における作業分析, 日本建築学会第 4 回「建 築生産と管理技術」シンポジウム論文集, pp. 31〜34, 1988. 7

4）田中舘豊, 藤澤好一, 吉田倬郎, 松留慎一郎：木造住宅の施工工 程と資材供給の同期化に関する研究, 日本建築学会第 6 回「建築 生産と管理技術」シンポジウム論文集, pp. 163 168, 1990.7

5）堀篭誠司, 神山幸弘, 岩井克巳, 堀圭吾, 村山隆：戸建住宅の複数 棟同時施工の実態分析：戸建住宅の MULTI-PROJECT SCHEDULING に関する研究その 1 , 日本建築学会第 6 回「建築 生産と管理技術」シンポジウム論文集, pp. 157〜 162, 1990.7

6）堀篭誠司，神山幸弘，村山隆, 斉藤昌典：戸建住宅の複数棟同時 施工の実態分析：戸建住宅の MULTI-PROJECT SCHEDULING に関する研究その 2 , 日本建築学会第 7 回「建築生産と管 理技術」シンポジウム論文集, pp. 169〜174, 1991. 7

7）堀篁誠司, 神山幸弘, 熊谷泰彦: 枠組壁工法住宅複数棟同時施工 の実態分析：その 1 基礎工事, 木工事の棟分担について, 日本建 築学会大会学術講演梗概集 F 分冊, pp. 971 972, 1994

8）熊谷泰彦, 神山幸弘, 堀篭誠司：枠組壁工法住宅複数棟同時施工 の実態分析：その 2 全職種の工事業者の実態分析および類型化, 日本建築学会大会学術講演梗概集 F 分冊, pp. 973 974, 1994

9) S. Matsudome, K. Fujisawa and T. Yoshida: Work •Breakdown Structure System for Japanese Timber House, CIB90 Building Economics Construction, Volume 6, pp. 301 312, 1990. 7

10) S. Matsudome, K. Fujisawa and T. Yoshida: Study on Synchronization between the Delivery of Materials and the Construction Process of Japanese Wood House, Construction Project Modelling and Productivity, pp. 195 200, 1991. 4

11) S. Matsudome, K. Fujisawa and T. Yoshida : Work Analysis on Framing of $2 \times 6$ Construction, Construction Project Modelling and Productivity, pp. 255 260, 1991. 4

[1995 年 6 月 25 日原稿受理 1995 年 8 月 25 日採用決定 $]$ 